Quarterly Progress Report

April 18, 2000

\title{
Biological Monitoring Program for East Fork Poplar Creek
}

\author{
Submitted to \\ M. C. Wiest \\ Environment, Safety and Health Organization \\ Lockheed Martin Energy Systems \\ Prepared by \\ Oak Ridge National Laboratory \\ Environmental Sciences Division \\ Oak Ridge, Tennessee 37831 \\ Managed by UT-Battelle, LLC, \\ for the \\ U.S. Dept. of Energy \\ under contract DE-AC05-00OR22725 \\ Contributors: \\ S. M. Adams \\ S. W. Christensen \\ M. S. Greeley, Jr. \\ W. R. Hill \\ J. F. McCarthy \\ M. J. Peterson \\ M. G. Ryon \\ J. G. Smith \\ G. R. Southworth \\ A. J. Stewart
}




\section{DISCLAIMER}

This report was prepared as an account of work sponsored by an agency of the United States Government. Neither the United States Government nor any agency thereof, nor any of their employees, makes any warranty, express or implied, or assumes any legal liability or responsibility for the accuracy, completeness, or usefulness of any information, apparatus, product, or process disclosed, or represents that its use would not infringe privately owned rights. Reference herein to any specific commercial product, process, or service by trade name, trademark, manufacturer, or otherwise, does not necessarily constitute or imply its endorsement, recommendation, or favoring of the United States Government or any agency thereof. The views and opinions of authors expressed herein do not necessarily state or reflect those of the United States Government or any agency thereof. 


\section{INTRODUCTION}

In May 1985, a National Pollutant Discharge Elimination System (NPDES) permit was issued for the Oak Ridge Y-12 Plant. As a condition of the permit, a Biological Monitoring and Abatement Program (BMAP) was developed to demonstrate that the effluent limitations established for the Y-12 Plant protect the classified uses of the receiving stream (East Fork Poplar Creek; EFPC), in particular, the growth and propagation of aquatic life (Loar et al. 1989). A second objective of the BMAP is to document the ecological effects resulting from the implementation of a water pollution control program designed to eliminate direct discharges of wastewaters to EFPC and to minimize the inadvertent release of pollutants to the environment. Because of the complex nature of the discharges to EFPC and the temporal and spatial variability in the composition of the discharges, a comprehensive, integrated approach to biological monitoring was developed. A new permit was issued to the Y-12 Plant on April 28, 1995 and became effective on July 1, 1995. Biological monitoring continues to be required under the new permit. The BMAP consists of four major tasks that reflect different but complementary approaches to evaluating the effects of the Y-12 Plant discharges on the aquatic integrity of EFPC. These tasks are (1) toxicity monitoring, (2) biological indicator studies, (3) bioaccumulation studies, and (4) ecological surveys of the periphyton, benthic macroinvertebrate, and fish communities.

Monitoring is currently being conducted at five primary EFPC sites, although sites may be excluded or added depending upon the specific objectives of the various tasks. Criteria used in selecting the sites include: (1) location of sampling sites used in other studies, (2) known or suspected sources of downstream impacts, (3) proximity to U.S. Department of Energy (DOE) Oak Ridge Reservation (ORR) boundaries, (4) concentration of mercury in the adjacent floodplain, (5) appropriate habitat distribution, and (6) access. The primary sampling sites include upper EFPC at kilometers (EFKs) 24.4 and 23.4 [upstream and downstream of Lake Reality (LR) respectively]; EFK 18.7 (also EFK 18 and 19), located off the ORR and below an area of intensive commercial and light industrial development; EFK 13.8 (also EFK 14), located upstream from the Oak Ridge Wastewater Treatment Facility (ORWTF); and EFK 6.3 located approximately $1.4 \mathrm{~km}$ below the ORR boundary (Fig. 1.1). Brushy Fork (BF) at kilometer (BFK) 7.6 is used as a reference stream in most tasks of the BMAP. Additional sites off the ORR are also occasionally used for reference, including Beaver Creek, Bull Run, Hinds Creek, Paint Rock Creek, and the Emory River in Watts Bar Reservoir (Fig. 1.2).

\section{TOXICITY MONITORING (M. S. Greeley, Jr. and A. J. Stewart)}

\subsection{Introduction}

The ambient toxicity monitoring task includes three subtasks: toxicity monitoring, toxicity experiments, and supporting studies. Toxicity monitoring uses U.S. Environmental Protection Agency (EPA) approved methods with Ceriodaphnia dubia and fathead larvae to provide systematic information that can be used to determine changes in the biological quality of EFPC through time. Toxicity experiments are conducted to test specific hypotheses about stream water quality. These hypotheses are addressed experimentally by the systematic application of ambient toxicity test methods. Supporting studies, often conducted using cost-effective student interns, are used to (1) investigate the relationship between the physicochemical and biological conditions in EFPC, particularly as they relate to processes or rates of ecological recovery and (2) develop better methods for accurately predicting ecological recovery accompanying changes in water quality in EFPC. Toxicity monitoring at EFK 24.1, a site just upstream of 


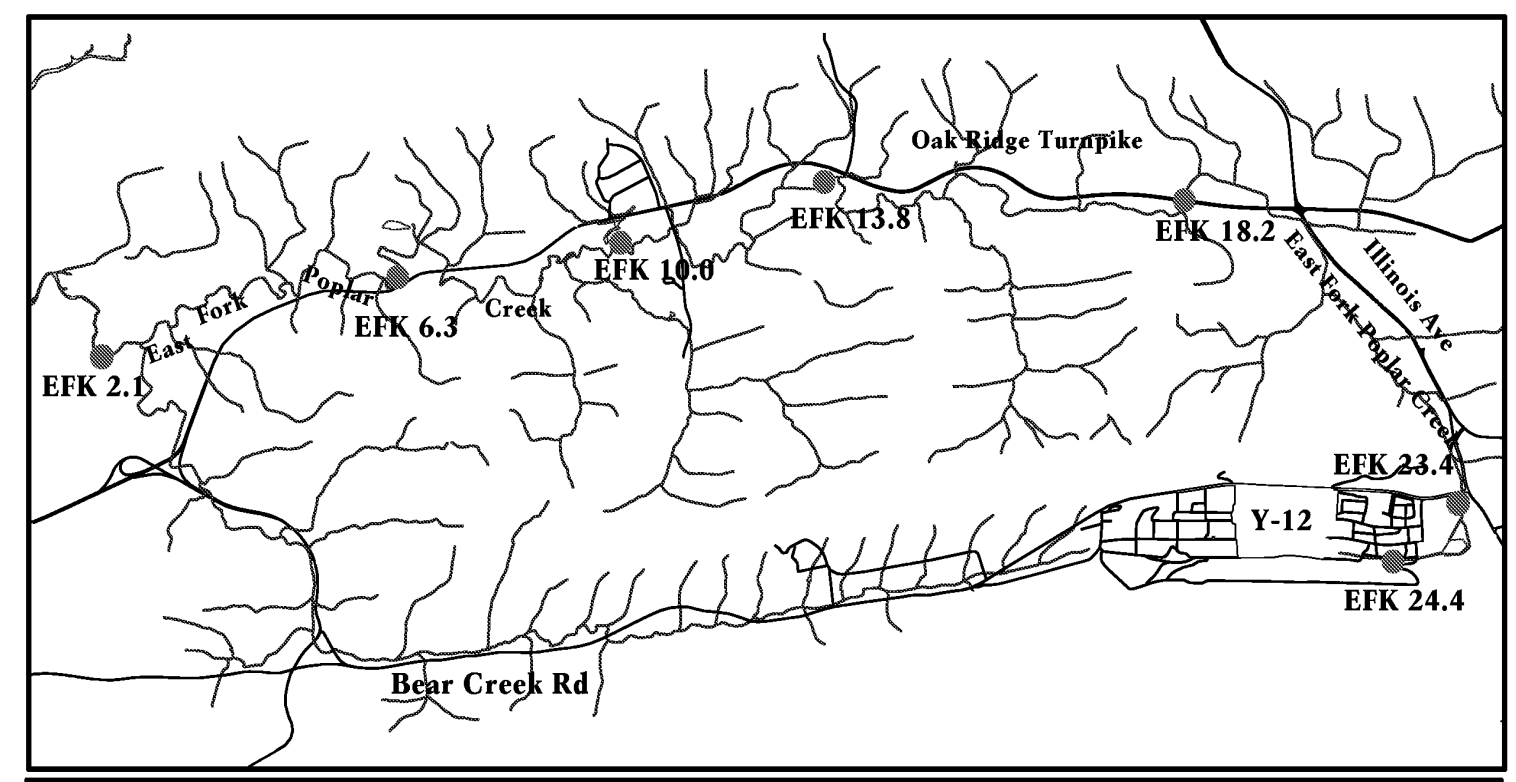

Y-12 Biological Monitoring and

Abatement Program

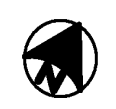

Scale

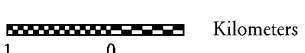

\begin{tabular}{|c||}
\hline \multicolumn{1}{|c||}{ LEGEND } \\
\hline SFK \# $\quad$ Sampling Location \\
Eest Fork Kilometer \\
\hline Tennessee State Plane Coordinate System, NAD 83 \\
\hline Source: Stream boundarys provided by the Oak \\
Ridge Environmental Resources \\
Information System (OREIS). \\
Prepared by Y-12 Biological Monitoring and \\
Abatement Program \\
Created: $95-12-12.13: 25$.Tues Version 1.0 \\
\hline
\end{tabular}

Figure 1.1. Location of biological monitoring sites on East Fork Poplar Creek in relation to the Oak Ridge Y-12 National Security Complex. 
O7NL-DWG-95M-7421

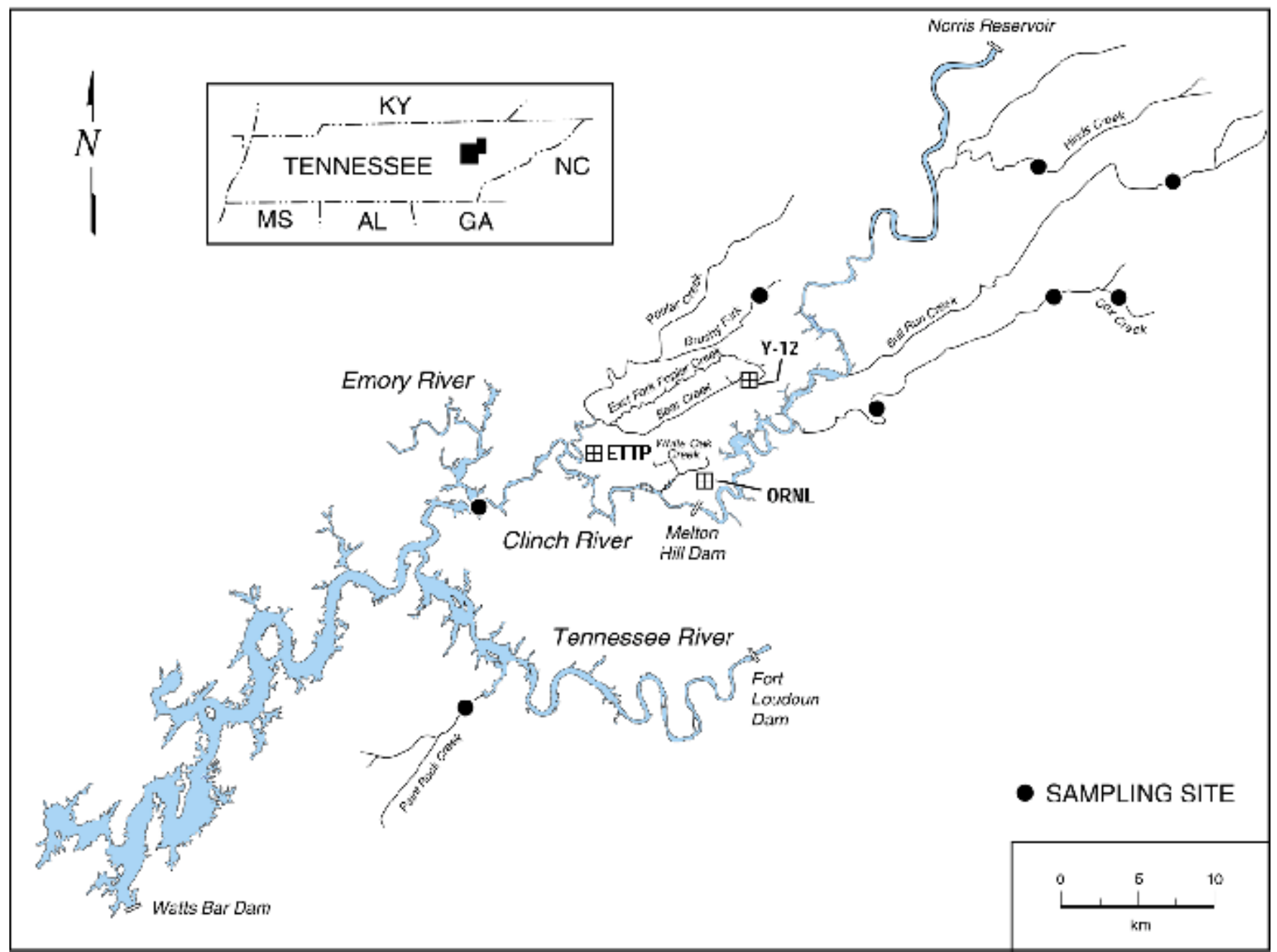

Figure 1.2. Location of biological monitoring reference sites in relation to the Oak Ridge Y-12 National Security Complex. 
Lake Reality, is conducted quarterly. Monitoring of EFK 23.8, immediately downstream of Lake Reality, has been discontinued as the bypass of Lake Reality made this site nearly synonymous with EFK 24.1. As required by the Y-12 Plant's National Pollutant Discharge Elimination System (NPDES) permit, quarterly toxicity tests with fathead minnows and Ceriodaphnia are conducted at Outfall 201 (an instream NPDES location in upper EFPC). The Outfall 201 tests meet the intent of the BMAP Plan to conduct quarterly toxicity tests at a nearby location, EFK 25.1. The results of the Outfall 201 tests are reported both here and on Discharge Monitoring Reports issued by the Y-12 Plant to the Tennessee Department of Environment and Conservation.

\subsection{Results/Progress}

\subsubsection{Toxicity monitoring}

Ambient water samples from EFK 24.1 and effluent samples from Outfall 201 were evaluated for toxicity to Ceriodaphnia dubia during January 19-26, 2000. On each sampling day, grab samples of stream water or 24-h time-proportional composite samples from Outfall 201 were collected for testing. Results of the toxicity tests and attendant water-quality chemical analyses are shown in Tables 2.1 and 2.2. During the test period, Ceriodaphnia survival was $100 \%$ in all samples. Ceriodaphnia reproduction in the stream water or effluent samples was not significantly different compared to the control. Samples from Outfall 201 were also evaluated for toxicity to fathead minnows (Pimephales promelas). Mean survival was $100 \%$ in both 80 and $100 \%$ concentrations, and growth in both concentrations $(0.70$ and 0.65 $\mathrm{mg} / \mathrm{larvae}$ respectively) exceeded growth of minnows in the control water (0.64 mg/larvae).

Table 2.1. Results of Ceriodaphnia dubia toxicity tests of ambient sites from East Fork Poplar Creek and Outfall 201 conducted January 19-26, 2000

\begin{tabular}{cccc}
\hline Sample & Concentration (\%) & Survival $(\%)$ & $\begin{array}{c}\text { Mean Reproduction } \\
\text { (offspring/surviving female } \pm \text { SD) }\end{array}$ \\
\hline Control & 100 & Ambient sites & \\
EFK 24.1 & 100 & 100 & $22.7 \pm 3.4$ \\
Control & 100 & 100 & $20.2 \pm 9.1$ \\
Outfall 201 & 100 & 100 & $22.7 \pm 3.4$ \\
Outfall 201 & 80 & 100 & $25.1 \pm 2.1$ \\
\hline
\end{tabular}

Note: $\mathrm{EFK}=$ East Fork Poplar Creek kilometer. SD = standard deviation. 


\subsubsection{Special Studies}

There were no toxicity special study activities to report for this quarter.

Table 2.2. Summary (mean \pm SD) of water chemistry analyses conducted during toxicity tests of ambient samples from East Fork Poplar Creek, January 19-26, 2000

\begin{tabular}{ccccc}
\hline Sample & $\begin{array}{c}\mathrm{pH} \\
(\mathrm{su})\end{array}$ & $\begin{array}{c}\text { Alkalinity } \\
\left(\mathrm{mg} / \mathrm{L} \text { as } \mathrm{CaCO}_{3}\right)\end{array}$ & $\begin{array}{c}\text { Hardness } \\
\left(\mathrm{mg} / \mathrm{L} \text { as } \mathrm{CaCO}_{3}\right)\end{array}$ & $\begin{array}{c}\text { Conductivity } \\
(\mu \mathrm{S} / \mathrm{cm})\end{array}$ \\
\hline Control & $8.21 \pm 0.17$ & $78.8 \pm 3.0$ & $94.7 \pm 5.0$ & $202.0 \pm 9.3$ \\
Outfall 201 & $7.90 \pm 0.11$ & $109.2 \pm 2.5$ & $140.3 \pm 5.3$ & $340.3 \pm 38.0$ \\
EFK 24.1 & $7.85 \pm 0.05$ & $113.2 \pm 2.5$ & $149.7 \pm 5.6$ & $376.7 \pm 83.4$ \\
\hline
\end{tabular}

Note $: \mathrm{EFK}=$ East Fork Poplar Creek kilometer. $\mathrm{SD}=$ standard deviation.

\section{BIOLOGICAL INDICATOR MONITORING}

\subsection{Bioindicators of Fish Health (S. M. Adams)}

\subsubsection{Introduction}

This task involves the use and application of bioindicators of fish health, in addition to other investigative approaches, to evaluate the effects of water quality and other environmental variables on fish in EFPC. A suite of diverse bioindicators of fish health has been monitored since fall 1985 to evaluate the health of a sentinel species, the redbreast sunfish (Lepomis auritus), as a component of the BMAP program.

\subsubsection{Results/Progress}

Growth is one of the better indicators of organism health because this measure integrates all the biotic and abiotic variables acting on an organism and reflects secondary impacts of chronic stress such as contaminant exposure. Growth of both male and females sunfish was compared between EFK 23, 14, and a reference site from 1990 through 1999 to determine if significant trends existed in the data relative to recovery effects. Growth in both male and female sunfish increased dramatically at EFK 23 following dechlorination practices in 1992, and remained relatively high for another three years from 1993-95 (Fig. 3.1). After water flow management was implemented in late 1996, however, growth rates for both sexes declined to pre-1993 levels and lower. Growth fluctuated more erratically at EFK 14, where the effects of remedial actions upstream at the Y-12 Plant could have been offset by the more localized effects of greatly increased erosion and sedimentation in this section of the stream. Reference site fish displayed no obvious temporal trends in growth over this same time period. 


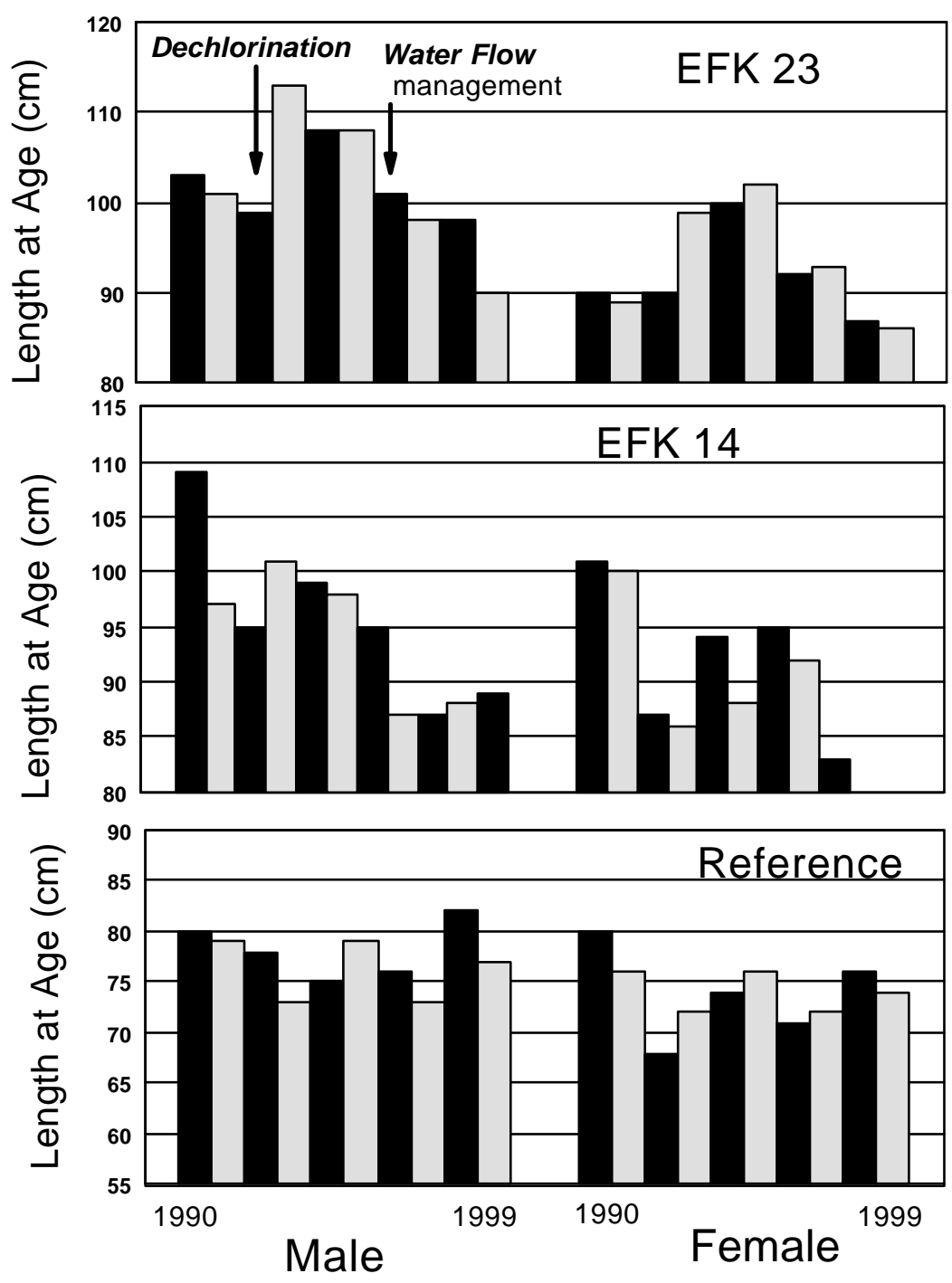

Fig. 1. Growth over a 10 year period of male and female redbreast sunfish at two EFPC sites and the reference site, Hinds Creek. 
Decreases in the growth rate of redbreast sunfish at EFK 23 after 1996 were most likely caused by flow management practices. Water added from Melton Hill Reservoir not only cooled the upper reaches of EFPC, but also lowered the nutrient levels in the stream. Cooler water temperatures, particularly during the spring and summer, would tend to reduced the length of the growing season for fish populations resulting in lower total annual growth. In addition, the added nutrient-poor water could effect primary and secondary production for upper-level consumers, a situation that would also contribute to lower overall annual fish growth. Two inter-related factors, therefore, probably account for the reductions in growth of redbreast sunfish in upper EFPC following water flow management: (1) a reduction in the growing season or period of time available for fish to grow at their optimum rate, and (2) a reduction in food consumption resulting in less energy available for somatic growth.

\subsection{Bioindicators of Reproductive Competence (M. S. Greeley, Jr.)}

\subsubsection{Introduction}

Successful reproduction of fish populations requires that adult fish be capable of producing and spawning viable gametes. To address the reproductive competence of fish in EFPC, various reproductive indicators, representing several different levels of reproductive organization related to gamete production, have been routinely examined in redbreast sunfish sampled from EFPC and reference streams at the beginning of each annual breeding season since 1988. Establishment and maintenance of stable fish populations also require that offspring be able to develop normally into subsequent reproductive cohorts. Beginning in 1990, water samples from several sites in EFPC and other streams on and about the ORR have been tested for their effects on fish developmental processes utilizing a variation of an EPAstandard medaka (Oryzias latipes) fish embryo-larval test (Benoit et al., 1991).

\subsubsection{Results/Progress}

A medaka embryo-larval developmental toxicity test was conducted on grab samples of water collected January 6, 2000 from seven sites in EFPC. Because recent tests had seen poor survival of medaka embryos in water from all EFPC sites, the current tests were conducted on both full-strength and 1/4-strength samples. Survival was uniformly poor in all full-strength samples, ranging from $50 \%$ at EFK 25.1 to $5 \%$ at a site downstream of the Oak Ridge Sewage Treatment Plant. Dilution increased survival significantly for most sites, with 1/4-strength samples from EFKs 24.6, 18.2 and 13.8 being indistinguishable from the control. The pattern of test results continues to indicate sources for the adverse effects of EFPC water on medaka development at both the Y-12 Plant and the sewage treatment plant.

As in several previous tests, survival actually decreased with dilution of water from EFK 25.1 (Table 3.1). In order to verify these results, a follow-up test was conducted on a wider range of dilutions for water from both EFK 25.1 and EFK 23.4 (Table 3.2). A clear dose-response was noted for the latter site $\left(\mathrm{LC}_{50}=50 \%\right)$. However, for EFK 25.1 an obvious dose-response was not observed until much lower concentrations ( $12.5 \%$ to $6.25 \%$ ) were tested, and even at these and lower concentrations the embryo responses did not occur in a predictable dose-response manner. These results suggest that several factors may be acting through very different mechanisms to affect survival at the upstream site, while further downstream at EFK 23.4 the exposure scenario may be much less complex. Ongoing toxicant identification and evaluation studies continue to focus on EFK 23.4. 
Table 3.1. Results of Medaka developmental toxicity tests of ambient sites from East Fork Poplar Creek initiated January 6, 2000

\begin{tabular}{|c|c|c|}
\hline Sample & $\begin{array}{c}\text { Survival at } 100 \% \text { sample } \\
(\%)\end{array}$ & $\begin{array}{c}\text { Survival at } 25 \% \text { sample } \\
(\%)\end{array}$ \\
\hline Control & 95 & n.a. \\
\hline EFK 25.1 & $50 *$ & $25^{*}$ \\
\hline EFK 24.6 & $15^{*}$ & 85 \\
\hline EFK 23.4 & $15^{*}$ & $55^{*}$ \\
\hline EFK 18.2 & $40^{*}$ & 100 \\
\hline EFK 13.8 & $45^{*}$ & 85 \\
\hline EFK 10.0 & $15^{*}$ & $25^{*}$ \\
\hline EFK 6.3 & $5^{*}$ & $20 *$ \\
\hline
\end{tabular}

\section{BIOACCUMULATION MONITORING}

\subsection{Routine Bioaccumulation Monitoring (M. J. Peterson and G. R. Southworth)}

\subsubsection{Introduction}

Bioaccumulation monitoring of EFPC has identified mercury and polychlorinated biphenyls (PCBs) as substances that accumulate to concentrations in fish that may pose health concerns to human consumers. Redbreast sunfish (Lepomis auritus) are collected twice annually from the mid to upper reaches of EFPC to evaluate spatial and temporal trends in mercury and PCB contamination. On an annual basis, largemouth bass (Micropterus salmoides) are collected to evaluate the maximum human health risks in EFPC and stoneroller minnows (Campostoma anomalum) are collected to evaluate the potential ecological concerns due to metal accumulation. For this quarter, reference fish from Hinds Creek were collected and all samples collected in winter of 1999/2000 were processed and submitted to the analytical laboratory.

\subsubsection{Results/Progress}

Redbreast sunfish and stonerollers were collected from Hinds Creek, an uncontaminated reference stream, in January 2000. Numerous trips were required to collect the fish needed. Increasingly in recent years it has been difficult to get fish from Hinds Creek, and it may be necessary to use another stream for reference fish in the future. Reference fish samples are important ecological and analytical controls for evaluating on-site contamination. 
Table 3.2. Results of Medaka developmental toxicity tests of water from EFK 25.1 and 23.4 initiated February 29, 2000

\begin{tabular}{lcl}
\hline Sample & Concentration & $\begin{array}{c}\text { Survival } \\
(\%)\end{array}$ \\
\hline Control & 100 & 100 \\
EFK 25.1 & 100 & $25^{*}$ \\
EFK 25.1 & 50 & $45^{*}$ \\
EFK 25.1 & 25 & $35^{*}$ \\
EFK 25.1 & 12.5 & $35^{*}$ \\
EFK 25.1 & 6.25 & $75^{*}$ \\
EFK 25.1 & 3.13 & $70^{*}$ \\
& & \\
EFK 23.4 & 100 & $35^{*}$ \\
EFK 23.4 & 50 & $50^{*}$ \\
EFK 23.4 & 25 & $75^{*}$ \\
\hline
\end{tabular}

Note $:$ EFK = East Fork Poplar Creek kilometer. Asterisk signifies a significant difference from the control at $\mathrm{p}=0.05$.

All EFPC redbreast sunfish and largemouth bass samples were processed and submitted to the analytical laboratory for mercury and PCB analysis. Stonerollers from one site (EFK 24.0) were submitted for metals analysis. The analytical results for mercury are expected shortly.

\subsection{Special Hg Studies}

Work was initiated on measuring the effects of various chemical sequestering agents on the bioavailability of mercury in EFPC. Iodide, an effect complexor of mercury at higher concentrations, was not found to be effective at trace (less than $1 \mathrm{ppm}$ ) concentrations at $\mathrm{pH} 7.5-8$ in initial studies. Work is continuing with sulfide and selenium compounds.

\subsection{PCB Source Identification (J. F. McCarthy)}

\subsubsection{Introduction}

Passive monitoring of polychlorinated biphenyls (PCB) using semipermeable membrane devices (SPMD) is being employed to determine the sources and sinks of PCBs at the Y-12 Plant. 


\subsubsection{Results/Progress}

PCB samples from SPMD deployments in 1996, 1997, 1998 and 1999 are being re-analyzed using gas-chromatography-mass spectroscopy to determine the concentrations of individual PCB congeners in each of the samples. Approximately 80 individual congeners are being quantified for each of the samples. The relative abundance of each congener becomes a "fingerprint" that can be used to identify and track the sources of PCBs. Principal Components Analysis (PCA; a statistical technique for comparing large multivariate datasets) will be used to evaluate the contribution of each PCB source to the inventory of PCBs within, and exiting, UEFPC. This approach will determine, for example, if the PCB congener "fingerprint" near Station 17 reflects the congener pattern arising from nonpoint source discharges along the creek, or exhibit a pattern reflecting inputs from outfalls or the storm sewer network.

Thus far, almost all the samples have been re-analyzed. Work is continuing to put all the data in worksheets that can create the SAS datasets necessary to perform the PCA.

\section{COMMUNITY STUDIES}

\subsection{Periphyton (W. R. Hill)}

\subsubsection{Introduction}

Periphyton monitoring in EFPC occurs four times a year (as close to a quarterly sampling regime as environmental conditions will allow). Rocks and their associated periphyton are collected from three sites in EFPC (EFKs 24.4, 23.4, 6.3) and one site in Brushy Fork (BFK 7.6). Four rocks from each site are used in determining algal biomass (chlorophyll $a$ ) and rate of photosynthesis $\left({ }^{14} \mathrm{C}\right.$ incorporation).

\subsubsection{Results/Progress}

There are no new results to report for the Periphyton task.

\subsection{Benthic Macroinvertebrate Community (J. G. Smith)}

\subsubsection{Introduction}

The objectives of the benthic macroinvertebrate task are to monitor the benthic macroinvertebrate community in EFPC in order to provide information on the ecological condition of the stream, and to evaluate the responses of macroinvertebrates to operational changes, abatement activities, or remedial actions at the Y-12 Plant as a measure of the effectiveness of these actions. To meet these objectives, quantitative benthic macroinvertebrate samples have been collected at least twice each year (April and October) since 1985 from five sites in EFPC (EFKs 24.4, 23.4, 18.7, 13.8 and 6.3), although only EFKs $24.4,23.4$, and 13.8 samples are routinely processed. Since 1986, up to two reference sites unimpacted by industrial discharges have also been monitored, including one site each on Brushy Fork (BFK 7.6) and Hinds Creek (HCK 20.6) (Figs.1.1 and 1.2). In addition to routine benthic macroinvertebrate community studies, an in situ bioassay, using a locally available clam as the test organism, is also conducted periodically. 


\subsubsection{Results/Progress}

There are no new results to report for the Benthic Invertebrate task.

\subsection{Fish Community (M. G. Ryon)}

\subsubsection{Introduction}

Fish population and community studies can be used to assess the ecological effects of water quality and/or habitat degradation. Fish communities, for example, include several trophic levels and species that are at or near the end of food chains. Consequently, they integrate the direct effects of water quality and habitat degradation on primary producers (periphyton) and consumers (benthic invertebrates) that are utilized for food. Because of these trophic interrelationships, the well-being of fish populations has often been used as an index of water quality. Moreover, statements about the condition of the fish community are easily understood by the general public.

The two primary activities conducted by the Fish Community Studies task in EFPC are: (1) biannual, quantitative estimates of the fish community at six EFPC sites and two reference stream sites; and (2) investigative procedures in response to fish kills near the Y-12 Plant. The quantitative sampling of fish populations is conducted by electrofishing during the March-April and September-October periods. The resulting data are used to estimate population size (numbers and biomass per unit area), determine length frequency, estimate production, and calculate Index of Biotic Integrity values. Fish kill investigations are conducted in response to chemical spills, unplanned water releases, or when dead fish are observed in EFPC. The basic tool used for fish kill investigations is a survey of upper EFPC (above Bear Creek Road to the N/S Pipes) in which numbers and locations of dead, dying, and stressed fish are recorded. This baseline is supplemented by special toxicity tests, histopathological examinations, and water quality measurements in an effort to determine the cause(s) of the observed mortality.

\subsubsection{Results/Progress}

Quantitative fish community sampling was begun for the EFPC sites and the reference sites during the 1st quarter 2000. Data from these quantitative surveys of EFPC sites will be entered into computer databases, processed through quality assurance procedures, and used to generate population estimates for density and biomass.

ESD responded to one fish kill during this quarter and conducted surveys of EFPC above Bear Creek Road on January 30, 2000. A spill on January 29 at approximately 18:00 reduced the pH near the North-South pipes from 7.5 to 4.9 for about 35 min. Measurements taken at Station 17 indicated the $\mathrm{pH}$ had declined to 5.9 at that locale. Following this alarm, water samples taken at 23:00 indicated a return to normal levels of $\mathrm{pH}$ and conductivity in upper EFPC. The next day, surveys were made of the stream from 11:00 to 12:40. A total of 52 dead fish were recovered including specimens of central stoneroller (Campostoma anomalum) and striped shiner (Luxilus chrysocephalus). Many live fish were seen in the creek, and no dying or stressed fish were observed. A follow up survey was made on February 1 at four downstream locations to determine if the slug of low $\mathrm{pH}$ water had affected fish populations off of the 
reservation. No dead fish were seen at these four locales.

\section{DATA MANAGEMENT (S. W. Christensen)}

\subsection{Introduction}

Environmental Compliance projects are required by provisions of the Oak Ridge Reservation Federal Facilities Agreement (FFA) and the State of Tennessee Oversight Agreement (TOA) to transmit their data to the Oak Ridge Environmental Information System (OREIS). BMAP data managers receive data packages from the PIs of the other tasks, transform the data into appropriate OREIS formats, and facilitate the data transfer to OREIS. This task also administers the BMAP workstation.

\subsection{Results/Progress}

During the 1st quarter 2000, data managers submitted fish bioaccumulation data from 1996-1999 and surface water toxicity monitoring data from July 1999 through March 2000 to OREIS. The Electronic Data Deliverable format for fish bioaccumulation data was revised to better support handling of fish data from reference sites, and to promote consistency with extractions of data from the BMAP data base. Because OREIS dropped their SAS license in March 2000, BMAP data managers developed and began implementation and use of infrastructure to convert from SAS to ASCII formats for Ready-to-Load transmittals to OREIS.

\section{SECOND QUARTER 2000 FIELD ACTIVITIES}

This section of the Y-12 BMAP quarterly report is meant to provide information to the Y-12 Environmental Compliance Office and other interested parties concerning BMAP plans for field activities in upper EFPC and adjacent environs during the upcoming calendar quarter.

Toxicity - Ambient water samples from EFK 24.1 and effluent samples from Outfall 201 will be evaluated for toxicity to Ceriodaphnia dubia during the $2^{\text {nd }}$ quarter 2000.

Bioindicators - The annual sampling of fish for the bioindicator task will be conducted at EFPC sites and two reference areas during the $2^{\text {nd }}$ quarter 2000. Because of declining fish populations and other indicators of impaired health, use of Brushy Fork as a reference site for the bioindicator task was discontinued after the 1999 sampling season. The stream will be replaced with a more suitable reference site, probably either the Little River or the Middle Prong of the Little Pigeon River. A medaka embryolarval TIE on ambient water samples from EFPC will be continued during the $2^{\text {nd }}$ quarter 2000.

Bioaccumulation - Routine spring sampling of EFPC for the bioaccumulation task begins in May.

Community Studies - Sampling for chlorophyll and photosynthesis at EFK 24.4, 23.4, and Brushy Fork will occur when two weeks without major heavy rains have passed. Benthic invertebrate sampling will occur in April. An in situ clam bioassay will be conducted in upper EFPC in June. Spring fish sampling in the EFPC drainage will be completed this quarter. 


\section{REFERENCES}

Benoit, D. A., G. W. Holcombe and R. L. Spehar. 1991. Guidelines for conducting early life stage toxicity tests with Japanese Medaka (Oryzias latipes). EPA/600/3-91/063. Environmental Research Laboratory - Duluth. Duluth, Minnesota.

Loar, J. M., S. M. Adams, L. J. Allison, J. M. Giddings, J. F. McCarthy, G. R. Southworth, J. G. Smith and A. J. Stewart. 1989. The Oak Ridge Y-12 Plant Biological Monitoring and Abatement Program for East Fork Poplar Creek. ORNL/TM-10265. Oak Ridge National Laboratory. Oak Ridge, Tennessee. 